\title{
Nitrogen Supply from Belowground Residues of Lentil and Wheat to a Subsequent Wheat Crop
}

\author{
R.L. Lemke ${ }^{1}$, M. Arcand ${ }^{2}$, J.D. Knight ${ }^{2}$, and R.E. Farrell ${ }^{2}$ \\ ${ }^{1}$ Agriculture \& Agrifood Canada, 107 Science Place, Saskatoon, SK S7N 0X2 \\ (email: reynald.lemke@agr.gc.ca) \\ ${ }^{2}$ Department of Soil Science, University of Saskatchewan, 51 Campus Drive, Saskatoon, SK \\ S7N 5A8
}

Keywords: Lentil, Wheat, Crop Residues, Nitrogen, Rhizodeposition, ${ }^{15} \mathrm{~N}$ labeling

\begin{abstract}
Lentil (Lens culinaris) plants can form an association with rhizobia and thereby biologically fix much of the nitrogen $(\mathrm{N})$ required for their growth. This not only reduces the need for expensive $\mathrm{N}$ fertilizer when the lentil crop is grown, but there is a potential to contribute a net increment of $\mathrm{N}$ to the soil that can be utilized by the subsequent crop. However, estimating this net increment of $\mathrm{N}$ remains a challenge, because of the difficulty in estimating the amount of root and rootderived $\mathrm{N}$. The purpose of this greenhouse study was to quantify the belowground $\mathrm{N}$ (BGN) of lentil and wheat (Triticum aestivum) using shoot ${ }^{15} \mathrm{~N}$ labeling and to trace the ${ }^{15} \mathrm{~N}$ from BGN into subsequently grown wheat plants. Belowground $\mathrm{N}$ comprised 34 and $51 \%$ of total plant $\mathrm{N}$ in lentil and wheat, respectively. Biomass production and $\mathrm{N}$ uptake by wheat grown on lentil belowground residues (BGR) were 49 and $14 \%$ higher than wheat grown on wheat BGR. Moreover, a higher proportion of added ${ }^{15} \mathrm{~N}$ from lentil BGN was recovered in the succeeding wheat crop, indicating that lentil BGN was more readily mineralized than wheat BGN. The disproportionately high increase in yield vs. $\mathrm{N}$ uptake for wheat grown on lentil BGR, however, indicates that non- $\mathrm{N}$ factors also contributed to the increase in wheat yield. This study highlights the importance of including estimates of BGN when evaluating the positive effects of including lentil crops in rotation with cereals.
\end{abstract}

\section{Introduction}

Benefits of including a pulse crop in the crop sequence of rotations on the Canadian prairies may be realized because of breaks in pest cycles, conservation of soil water, reduced weed pressure, and other possible rotational effects such as improved rhizosphere biology. Pulse crops, in association with rhizobia, can biologically fix much of their own nitrogen $(\mathrm{N})$ supply during their growth cycle, thus reducing the need for expensive $\mathrm{N}$ fertilizer. Associated "nitrogen" benefits include the sparing of indigenous soil $\mathrm{N}$, provision of relatively $\mathrm{N}$-rich crop residues that release $\mathrm{N}$ for use by subsequent crops following decomposition and, the potential to contribute a net 
increment of $\mathrm{N}$ to soil if $\mathrm{N}$ fixation rates are high. However, estimating this net increment of $\mathrm{N}$ remains a challenge, because of the difficulty in estimating the $\mathrm{N}$ supplied from decomposing BGR and the amount of root-derived N (e.g. root exudates). Some workers have estimated that root-derived N comprises as much as 80 \% of total BGN (Mayer et al. 2003; Wichern et al. 2007; Arcand et al. 2013).

Studies using shoot ${ }^{15} \mathrm{~N}$ labeling enables the full determination of BGN, and can be used to directly track the release of ${ }^{15} \mathrm{~N}$ from $\mathrm{BGN}$ to subsequent crops. Lentil (Lens culinaris ) production on the Canadian prairies is on the increase and, according to a recent agricultural census, lentil surpassed field pea (Pisum sativum) in total land area under production (Statistics Canada 2011). To our knowledge, no studies have examined total BGN in lentil, nor the contribution of BGN of lentil to a subsequent crop. The objective of this study was to quantify BGN, including $\mathrm{N}$ rhizodeposition produced by lentil and hard red spring wheat (Triticum aestivum), and to determine the supply of $\mathrm{N}$ from BGN of lentil and wheat to a following wheat crop. Wheat was included as a comparison with lentil and to compare with values reported in the literature. The potential yield benefit of growing wheat on lentil relative to wheat BGN was also evaluated.

\section{Materials \& Methods}

The study was conducted under controlled conditions in a greenhouse. Lentil plants were grown in acrylic pots $(12.7 \mathrm{~cm}$ i.d., $30 \mathrm{~cm}$ deep). Soil for the pots was collected from an agricultural field site near Swift Current, SK. The soil was air-dried, sieved (2 $\mathrm{mm}$ ) to remove any rocks, and mixed with silica sand in a 1:1 (w/w) ratio. The resulting soil-sand medium was sandy loam texture with a pH of 7.1 (1:2 soil: $\left.\mathrm{H}_{2} \mathrm{O}\right)$. Soils were packed to a bulk density of $1.54 \mathrm{~g} \mathrm{~cm}^{-3}$. The pots were arranged on a greenhouse bench with eight replicate pots for the ${ }^{15} \mathrm{~N}$-labeled plants (lentil and wheat) and four replicate pots for the natural abundance control plants (lentil and wheat). An additional and identical set of pots was prepared for use in the second rotational phase of the study; therefore, there were a total of 48 pots. Lentil and wheat plants were supplied with ${ }^{15} \mathrm{~N}$-enriched urea using the cotton-wick method (Russell and Fillery 1996). At harvest aboveground plant components were separated into residues (stem, leaves, pod walls, and chaff) and seed. Visible roots and root fragments were collected from the soil.

Soil and plant samples were analyzed for $\mathrm{N}$ concentration (\%) and atom $\%{ }^{15} \mathrm{~N}$ using an elemental analyzer coupled to an isotope ratio mass spectrometer respectively. Atom $\%{ }^{15} \mathrm{~N}$ excess values were calculated by subtracting atom $\%{ }^{15} \mathrm{~N}$ values of soils and plants under natural abundance conditions from atom $\%{ }^{15} \mathrm{~N}$ of labelled soils and plants. The percentage of soil $\mathrm{N}$ derived from rhizodeposition (\%NdfR) was calculated as the atom $\%{ }^{15} \mathrm{~N}$ excess of the roots divided by the atom $\%{ }^{15} \mathrm{~N}$ excess of the soil. 


\section{Results and Discussion}

Wheat accumulated $81 \%$ more total biomass than lentil on a per plant basis, however total plant $\mathrm{N}$ uptake was greater for lentil than for wheat due to high $\mathrm{N}$ accumulation in the shoots. Nitrogen partitioning differed between lentil and wheat for all soil and plant components. Total BGN (i.e., root $\mathrm{N}+$ root-derived $\mathrm{N}$ ) comprised 34 and $51 \%$ of total plant $\mathrm{N}$ in lentil and wheat, respectively. Belowground N comprised 46 and $84 \%$ of the total (AGR + roots + rhizodeposits) crop residue $\mathrm{N}$ balance in lentil and wheat, respectively.

Table 1. Relative distribution of nitrogen for lentil plants grown in pots in a greenhouse compared to values reported in the literature.

Source

\begin{tabular}{lccc} 
& Grain-N & AGR-N & BGN \\
\hline & & $\%$ & \\
This Study & 26 & 30 & 34 \\
Gan et al. 2010 & 56 & 30 & $14 *$ \\
Janzen et al. (2003) & 65 & 25 & $10 *$ \\
\hline
\end{tabular}

* Root-derived N (Rhizodeposition) not included

A comparison of the distribution of $\mathrm{N}$ from lentil in our study compared to other literature values is provided in Table 1 . There is considerable variability between the reported values. Note in particular the higher BGN distribution in our study compared to the literature values. We speculate that the substantially higher BGN values reported in our study are the result of including direct estimates of root-derived N. Higher BGN values have important implications with regard to the overall $\mathrm{N}$ fertility of rotations that include lentil in the crop sequence. For example, after reviewing the literature, Janzen et al. (2003) reported that mean grain-N, aboveground residue $\mathrm{N}$ (AGR-N) and below-ground $\mathrm{N}$ for lentil represent 65, 25 and $10 \%$ of total plant N, respectively (Table 2). However, the studies reviewed by Janzen et al. (2003) did not include estimates of root-derived $\mathrm{N}$, therefore the amount of BGN was assumed to be relatively low. If we recalculate the $\mathrm{N}$ distribution using the increased BGN values reported in our study, the resulting distribution of $\mathrm{N}$ would be 48, 18 and $34 \%$ of total plant $\mathrm{N}$ for grain $\mathrm{N}, \mathrm{AGR}-\mathrm{N}$ and $\mathrm{BGN}$, respectively. To place this in context, we'll use the relative $\mathrm{N}$ distributions to calculate an actual $\mathrm{N}$ contribution for a hypothetical lentil crop having a seed yield of $1700 \mathrm{~kg} \mathrm{ha}^{-1}$, and a grain $\mathrm{N}$ concentration of 4.4\%. Using the distribution values reported by Janzen et al. (2003), this would result in a total plant $\mathrm{N}$ of $115 \mathrm{~kg} \mathrm{~N} \mathrm{ha}^{-1}$. Assuming that about $60 \%$ of the total plant $\mathrm{N}$ was fixed by the plant-rhizobia association, this means that about $69 \mathrm{~kg} \mathrm{~N}$ (115 kg N x 60\%) 
was supplied from the atmosphere and $46 \mathrm{~kg} \mathrm{~N}$ was scavenged from the soil. If $75 \mathrm{~kg}$ of $\mathrm{N}$ is removed in the grain and the lentil crop only supplied $69 \mathrm{~kg} \mathrm{~N}$ via biological fixation, then more $\mathrm{N}$ (about $6 \mathrm{~kg} \mathrm{~N} \mathrm{ha}^{-1}$ ) was removed in the grain than was supplied via biological fixation, and there will be a small net loss of $\mathrm{N}$ when the lentil crop is harvested. However, using the recalculated $\mathrm{N}$ distribution based on the BGN values reported in our study, the same lentil crop would have an estimated total plant $\mathrm{N}$ of $156 \mathrm{~kg} \mathrm{~N} \mathrm{ha}^{-1}$. If $60 \%$ of this was fixed by the plantrhizobia association (156 kg N x 60\% = $94 \mathrm{~kg} \mathrm{~N}$ ), and the same $75 \mathrm{~kg} \mathrm{~N}$ is removed in the grain, then there would be an overall net $\mathrm{N}$ benefit of $19 \mathrm{~kg} \mathrm{~N}(94-75=19 \mathrm{~kg} \mathrm{~N})$. We acknowledge that it is perilous to extrapolate results from a greenhouse study to a field situation; however this simple hypothetical scenario does clearly demonstrate the importance including estimates of root-derived $\mathrm{N}$ when determining the overall $\mathrm{N}$ contribution of a lentil crop.

Table 2. Comparison of the relative distribution of nitrogen for lentil crops reported in the literature and adjusted based on results of current study.

Nitrogen Distribution

Grain-N AGR-N BG-N Total $\mathrm{N} \quad \mathrm{N}_{\text {inc }}{ }^{*}$

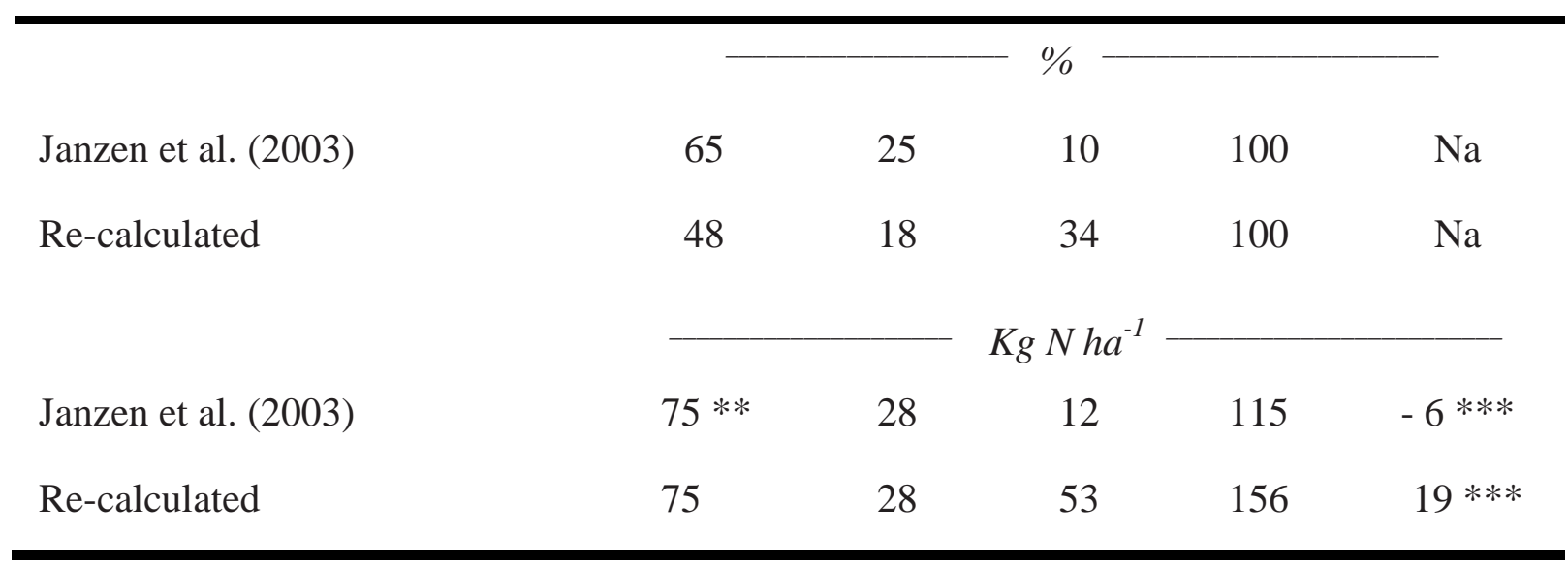

* $\quad$ Ninc $=$ biologically fixed $\mathrm{N}-\mathrm{N}$ removed in grain

** Assuming an average yield of $1700 \mathrm{~kg} \mathrm{ha}^{-1}$ translating into a grain-N of about $75 \mathrm{~kg} \mathrm{~N} \mathrm{ha}{ }^{-1}$

*** Assuming $60 \%$ of the crop $\mathrm{N}$ was derived from biological fixation

In the second phase of this study, wheat was grown in the pots containing BGR of lentil or wheat. Total biomass of wheat grown on lentil residue was $49 \%$ higher compared to wheat grown on wheat residues. Moreover, a higher proportion of the ${ }^{15} \mathrm{~N}$ in the lentil BGR (14.4 vs. $8.5 \%$ ) was recovered in the succeeding wheat crop, indicating that lentil BGN was more readily mineralized than wheat BGN. The disproportionately high increase in yield vs. N uptake for wheat grown on lentil BGR, however, indicates that non-N factors also contributed to the increase in wheat yield.

This study highlights the importance of including estimates of BGN when evaluating the positive effects of including pulse crops in rotation with cereals. 


\section{References}

Arcand MM, Knight JD, Farrell RE (2013) Estimating belowground nitrogen inputs of pea and canola and their contribution to soil inorganic $\mathrm{N}$ pools using ${ }^{15} \mathrm{~N}$ labeling. Plant Soil 371: 67-80

Gan YT, Campbell CA, Janzen HH, Lemke RL, Basnyat P, McDonald CL (2010) Nitrogen accumulation in plant tissues and roots and $\mathrm{N}$ mineralization under oilseeds, pulses, and spring wheat. Plant Soil 332:451-46

Janzen HH, Beauchemin KA, Bruinsma Y, Campbell CA, Desjardins RL, Ellert BH, and Smith EG (2003) The fate of nitrogen in agroecosystems: An illustration using Canadian estimates Nutr Cycl Agroecosys 67:85-102

Mayer J, Buegger F, Jensen ES, Schloter M, Heß J (2003) Estimating N rhizodeposition of grain legumes using a ${ }^{15} \mathrm{~N}$ in situ stem labelling method. Soil Biol Biochem 35:21-28

Russell CA, Fillery IRP (1996) In situ ${ }^{15} \mathrm{~N}$ labelling of lupin belowground biomass. Aust J Agric Res 47:1035-1046

Statistics Canada (2011) 2011 Census of Agriculture. Ottawa, ON

Wichern F, Mayer J, Joergensen RG, Müller T (2007) Rhizodeposition of C and N in peas and oats after ${ }^{13} \mathrm{C}-{ }^{15} \mathrm{~N}$ double labelling under field conditions. Soil Biol Biochem 39:2527-2537 